\title{
INSURING THE NATION'S DESTINY: REDUCING THE DIGITAL DIVIDE
}

\author{
William Booth
}

Hampton University

\begin{abstract}
"Closing the digital divide is a national challenge among historically black colleges and universities (HBCUs)," writes White examining the state of information technology readiness of five four-year HBCUs in the Commonwealth of Virginia [1]. The inequalities created by the digital divide have the potential of undermining the effort of HBCUs in educating an "African American workforce capable of fully participating in a global information economy” [1, p.13].
\end{abstract}

The National Association for Equal Opportunity in Higher Education (NAFEO), a nonprofit Black college association representing the interests of HBCUs in its HBCU Technology Assessment Study (TAS) produced the most comprehensive report of its kind in assessing the computing resources, networking, and connectivity of the Historic Black Colleges and University serves as the primary source for this narrative [2].

\section{KEYWORDS}

Historically Black Colleges and Universities (HBCUs), Digital Divide, Networking, Connectivity

\section{WHO ARE THE HBCUS?}

There are 118 HBCUs when the definition embraces not only the postsecondary institutions founded prior to the Civil Rights Act of 1964 with the primary objective of educating African-Americans, but also those colleges and universities referred to by NAFEO as "Other Equal Opportunity Educational Institutions" (EOEI). The latter institutions were founded after 1963 and enroll a plurality of black and other minorities.

HBCUs and EOEIs are located in 24 states, the District of Columbia, and the Virgin Islands and are found in large urban cities, suburbs, and small rural towns. Their respective campus communities serve over 350,000 students and have been instrumental providing graduates for key positions in major organizations, including government, business, and education. Of signal significance is that these institutions, whose foci are liberal arts, business, agriculture, research, science, and technology and graduate more African-American students to fill the ranks of professionals in medicine, dentistry, pharmacy, and teaching than all other institutions in the United States. A little less than $50 \%$ (46\%) of HBCUs are public institutions funded by their state governments, and more than $50 \%(54 \%)$ are private institutions, a number of which are supported by national religious denominations. HBCUs and EOEIs include accredited two-year, four-year, and graduate and professional institutions.

Multi-racial staffs and diverse student populations, including white students, compose the collegiate communities of the HBCUs and EOEIs. HBCUs have their highest concentration in the South, but also 
are located in the Midwest, Mid-Atlantic Region, the Far West, and the Virgin Islands.

HBCUs educate significant numbers of African-American professionals in the disciplines of higher education at the baccalaureate, masters, doctoral, and post-doctoral levels. These predominately AfricanAmerican students go on to lead important organizations in their communities and contribute to the nation's productivity in all of the major industry sectors including the emerging technology sectors vital to the new economy.

\section{WHAT IS THE CONNECTIVITY STATUS OF HBCUS?}

TAS drew its data from 80 of the 118 HBCUs, or $67 \%$. A reasonable conclusion to be drawn from those reporting is that most HBCUs are solidly on the on-ramp of the information superhighway. Ninety-eight percent of the institutions that responded reported the existence of data, voice and/or data and voice campus networks, at mostly T-1 connectivity speeds, and most had basic access to the Internet, World Wide Web and campus networks.

Dr. Larry Earvin, President of Huston-Tillotson College in Austin, Texas, speaking on behalf of The United Negro College Fund, many of whose member institutions are among the HBCUs or EOEIs, before the House Science Committee's Subcommittee on Research [3] enumerated the impacts of the \$80 million Technology Enhancement Capital Campaign (TECC) set in motion by the United Negro College Fund (UNCF) partnership with Microsoft, IBM, AT\&T and other major corporations:

- In Texas, four member colleges-Paul Quinn College, Huston-Tillotson College, Jarvis Christian College and Wiley College-received from UNCF \$8.3 million. With their share of the technology funds, Huston-Tillotson was able to purchase and implement a state of the art, voiceover IP solution. Furthermore, the college also implemented a wireless LAN that expands the entire campus;

- In Florida, where UNCF has three member colleges-Bethune-Cookman College, Edward Waters College, and Florida Memorial College-UNCF provided \$6.6 million in technology funds. One example of the use of the funds is that Bethune-Cookman established a quality infrastructure for storage and distribution of applications and data;

- In North Carolina, there are six member colleges and universities-Johnson C. Smith University, Shaw University, St. Augustine's College, Barber Scotia College, Bennett College and Livingstone College. Here UNCF has invested \$13.7 million in technology. With its portion of the funds, Johnson C. Smith University developed a print solution and a robust e-mail system;

- In Georgia, UNCF colleges and universities, including Clark Atlanta University, Interdenominational Theological Center, Morehouse College, Spelman College and Paine College, received a total investment of \$18.0 million. At Clark Atlanta University, computer lab capability and access were enhanced, with improved security;

- In Virginia, there are two member institutions, St. Paul's College and Virginia Union University, where UNCF funded \$2.7 million in technology. As an example, Virginia Union University established a totally wireless campus and created mathematics computer labs for classroom teaching and accounting computer labs for teaching and student exercises;

- In Tennessee, three UNCF institutions-Fisk University, Lane College and LeMoyne-Owen College-received a total investment of $\$ 6.0$ million. Fisk University installed computers in the dorms, improved its web site and enhanced networking capabilities;

- In Alabama, there are five UNCF member institutions, Miles College, Oakwood College, Stillman College, Talladega College, and Tuskegee University, where UNCF funded \$12.5 million in technology. Tuskegee University wired its entire campus, enabling it to provide access 
to students and faculty campus-wide;

- In addition, all 39 UNCF campuses have benefited from upgraded network infrastructures and increased access to technology for students, faculty, and staff;

- UNCF institutions have received hardware, including 5,500 desktop computers, almost 1,800 network printers, nearly 2,000 network servers, and about 2,000 laptops, as well as hundreds of hubs, switches and network routers, courtesy of Hewlett Packard, Cisco, Lexmark, Dell and Pfizer;

- The wiring of member institution campuses is completed-including over 3,800 network drops in learning centers and administrative and academic facilities and equipment installation and configuration; and

- UNCF member institution received 145,000 current versions of Microsoft, including Windows 2000, Encarta Reference Suite 2000, Microsoft Office Suite 2000, Windows XP, and Encarta Africana 2000 courtesy of an 'in-kind' gift from Microsoft [3].

\section{WHERE ARE THE DIGITAL GAPS?}

\section{A. HBCU Student Access}

Among the troubling digital divide concerns is that fewer than $25 \%$ of HBCU students own their own computers. HBCU students cannot access campus networks from their dorms, even through a telephone line, since they do not own the necessary equipment. Instead, students must rely on common resources provided by their institutions. Fifty percent of HBCUs campuses provide 'on demand' student access to computing resources, but access is not available at a critical location-the campus dormitory. In contrast the Campus Computing Study [4], the largest continuing study of computing and information technology in American higher education, reported that among all institutions of higher education, $62 \%$ of dormitory beds have network connections thereby providing students who own their own computer with direct access on demand.

Furthermore, only $13 \%$ of HBCUs recommend that students own their own computers, compared to $30.5 \%$ of all institutions of higher education. If the 80 HBCUs responding only two institutions, or 3\%, indicated that financial aid was available from their institutions to assist with the purchase of computers. Money Matters: The Impact of Race/Ethnicity and Gender on How Students Pay for College [5] found $36 \%$ of African-American students have income and assets that are so limited that the government does not expect them to make any contribution to their college education; another $25 \%$ are expected to contribute only $\$ 2,500$ annually; among HBCU students paying their own way through college, almost $64 \%$ have annual incomes of less than $\$ 20,000$ and 39\% have less than $\$ 10,000$ making it difficult if not impossible for HBCU students to have the financial wherewithal to purchase their own computers.

Dr. Earvin of Huston-Tillotson observed that the digital deficit experienced by HBCU students is exacerbated by the fact that, "minority students have been raised in families without a computer in the home, attended poor urban and rural schools that were not equipped with $21^{\text {st }}$ Century technology, and have been taught by educators who may have had less facility with computers than their students” [6].

\section{B. Bandwidth Issues}

HBCUs usage of higher bandwidth technologies for accessing the Internet, World Wide Web, and other networks indicates that HBCUs are not using high-speed connections, even if those connections are available in their communities, which lead the researchers to surmise that it was due to the absence of finance, lack of strategic planning, faculty motivation, and training. White found that only one of the five 
HBCUs studied had a membership in the Internet 2 environment. The CIO at another of the institutions expressed interest in his/her research faculty joining but had no timeline [1, p.84].

\section{Faculty Utilization}

The TAS study revealed Web-based resources were used infrequently in the classroom. Limited use of groupware and intranets, few professional meetings and little professional collaboration over the internet signaled minimal faculty utilization.

In addition, the results indicate that work is needed in the area of integrating technology into the classroom. HBCU faculty and staff must understand that they will be measured, in coming years, on their ability to participate in networks and provide students with global access to knowledge.

A response to one of the survey queries as to whether faculty and academic units are effective at using the Internet and World Wide Web as a resource for curriculum and instruction indicated that they were "somewhat effective." Predictably, HBCUs suggested that the library, computer science, and technology units were most effective while the foreign language, humanities, and fine arts departments were least effective. Clearly a shortfall was that none of the respondents indicated that any of their academic or faculty units were "extremely effective" with using the Internet in the classroom.

\section{Other Vulnerable Areas}

Leaving much to be desired was awareness regarding the importance of network security and maintenance of technology strategic plans.

A particularly unsettling finding of the TAS team was that private HBCUs located in rural areas with student populations of 999 or less report a significant gap in connectivity, equipment, student access, and overall computing resources. Still another vulnerable area is in degrees offered through distance education. Eighty-five percent of the institutions report that they are not offering distance learning degrees programs at the present time. Forty-eight percent of them indicate that they do plan to offer distance learning degree programs within the next three years. Twenty percent of HBCUs indicate that they have no plans to offer distance learning degree programs within the next three years, and $30 \%$ did not know. The number of respondents reporting that they did not know their institutions' plans regarding distance learning may indicate weakness in institutional strategic planning. As distance learning grows as an option for providing higher education and academic degrees the question of how HBCUs should participate further in the world of distance learning becomes an important administrative, strategic, and academic issue for colleges to evaluate.

It is evident that in order to move toward digital equity the all too prevalent weaknesses in HBCUs network need shoring in the following areas: (1) encouraging, increasing, and funding student ownership of computers; (2) expecting faculty to use technology, and training, and rewarding faculty for integrating technology into their pedagogical methodology; (3) foregrounding strategic planning for future technology and infrastructure; and (4) networking and partnering between and among HBCUs to bridge the gaps that funding from other sources cannot or will not provide, thus avoiding the further erosion of their viability as institutions of higher learning.

There is some reassurance in the fact that HBCUs are not in the "dark ages" of networking and connectivity. However, unless continual upgrading becomes part and parcel of the culture of HBCUs, a 
manageable digital divide today can evolve into an unmanageable digital gulf tomorrow.

\section{ABOUT THE AUTHOR}

William D. Booth, D.Min., is the director of the religious studies program and assistant professor of ethics at Hampton University in Hampton, Virginia. The religious studies program is 5 years old; funded by the Alfred P. Sloan Foundation; it is one of the few religious studies programs online and the only one from an HBCU. Dr. Booth represents the program for eArmyU; the program was also made available to Sloan Semester students who were affected by Hurricane Katrina.

\section{REFERENCES}

1. White, D. S. "An Examination of the State of Information Technology Readiness at the Five FourYear Historically Black Colleges and Universities (HBCUs) in the Commonwealth of Virginia,” 13. Diss. George Washington University, 2004.

2. Department of Commerce \& NAFEO. Historically Black Colleges and Universities: An Assessment of Networking and Connectivity. Washington, D. C., October, 2000.

3. United States. Cong. House Science Committee-Subcommittee on Research. Hearing on H. R. 2183, the Minority Serving Institutions Digital and Wireless Technology Opportunity Act, July 9, 2003. http://www.house.gov/science/hearings/research03/jul09/earvin.htm.

4. Green, K .C. College Struggles with IT Planning, The Campus Computing Project, 1998.

5. King, J. Money Matters: The Impact of Race/Ethnicity and Gender on How Students Pay for College. Washington D. C.: American Council on Education, 1999 (updated 2003). http://www.acenet.edu /bookstore/pubInfo.cfm?pubID=61.

6. Falling Through the Net: A Report on the Telecommunications and Information Technology Gap in American. Washington D.C.: National Telecommunications and Information Administration, July 1999. http://www.ntia.doc.gov/ntiahome/fttn99/contents.html. 